\title{
La construcción en cantería en la Galicia barroca. Las monteas del coro alto de la capilla de San Telmo de Tui
}

\author{
Ashlar construction in Galicia in the Baroque period. The \\ tracings in the tribune of the chapel of Saint Telmo in Tui
}

L. Calvo-López ${ }^{(*)}$; M. A. Alonso-Rodríguez ${ }^{(* *)}$; M. Taín-Guzmán ${ }^{(* * *)}$; P. Natividad-Vivó ${ }^{(*)}$

\section{RESUMEN}

La construcción en piedra de cantería exige el empleo de medios geométricos de mayor o menor complejidad para controlar tanto la disposición general de la pieza como la forma de los elementos individuales de la fábrica. En este artículo se describe y analiza un grupo significativo pero poco conocido de estos trazados, localizados en la capilla de San Telmo en Tui, relacionados con varios elementos de la fachada de la capilla. Se ha practicado un levantamiento de los trazados por rectificación fotográfica y otro de los elementos más significativos de la fachada mediante una estación total. Todo esto nos permite identificar los referentes del trazado y obtener datos de primera mano acerca de los métodos de control formal empleados en la construcción barroca y de los procesos de adaptación del proyecto real a los condicionantes de la ejecución, que no ofrecen los tratados y manuscritos de la época.

$970-11$

Palabras clave: Cantería; estereotomía; monteas; arquitectura barroca; Galicia; Tui; Capilla de San Telmo; Domingo de Novás y Lemos.

\section{SUMMARY}

Construction in hewn stone requires the use of geometrical means in order to control both the general layout of the built member and the shape of the individual masonry elements. Fullsize tracings have been used with this purpose since Classical Antiquity. In this paper, we shall describe and analyse a not-so-well-known example of these tracings, in the chapel of Saint Telmo in Tuy, which are connected with the façade of the chapel. We have carried out a survey of the ensemble of the tracings by means of rectified photographs; at the same time, we have prepared a survey of the most significant elements in the façade, using a laser total station, in order to compare the tracings with the built chapel. All this has allowed us to gather valuable first-hand information about the formal control methods used in Baroque construction that treatises and manuscripts cannot furnish directly.

Keywords: Stonecutting; stereotomy; tracing floors; Baroque architecture; Galicia; Tui; Chapel of Saint Telmo; Domingo de Novás y Lemos.

\footnotetext{
(*) Universidad Politécnica de Cartagena (España)

(**) Universidad Politécnica de Madrid (España)

(***) Universidade de Santiago de Compostela (España)

Persona de contacto / Corresponding author: jose.calvo@upct.es (J. Calvo-López)
}

Recibido/Received: 14 feb 2013 Aceptado/Accepted: 29 abr 2013 


\section{LAS MONTEAS DEL CORO ALTO DE LA CAPILLA DE SAN TELMO EN TUI}

Desde la Antigüedad se han empleado trazados a tamaño natural con el fin de controlar tanto la disposición general de las piezas de fábrica como la forma de los sillares y dovelas de las construcciones en piedra de cantería (1). En algunas ocasiones estos dibujos, conocidos en español como trazas o monteas, se realizaban exactamente debajo de la pieza a construir, lo que permitía controlar la labra de la piedra y posteriormente verificar su asiento; con gran frecuencia, se empleaban para este fin lugares apartados del paso, como terrazas, galerías o espacios bajo escaleras (2) (3) (9) (10). En otros casos, para facilitar la organización de la obra, todos o gran parte de los trazados se realizaban en un mismo lugar, conocido como casa de la traza o tracing house. En la Inglaterra medieval, tenemos documentos de archivo que aluden a la trasura de Westminster Palace (4), y se han conservado las de las catedrales de York (5) (6) y Wells (6) (7). En España, han Ilegado hasta nosotros las de las catedrales de Sevilla (8) y Santiago de Compostela (9) (10); también existen referencias documentales a las salas de trazas de la catedral de Granada (11) y el Monasterio de El Escorial (12), todas ellas de la Edad Moderna.

En este trabajo, nos proponemos describir y analizar un ejemplo significativo de estos trazados, los dispuestos en el coro alto de la capilla de San Telmo en Tui (10). A pesar de sus reducidas dimensiones, 5,89 x 2,87 m, este espacio alberga un gran número de trazados de cantería, que ofrecen una prueba excepcional del dominio de la estereotomía alcanzado por los maestros del noroeste de España. Las monteas están materializadas mediante incisiones practicadas con trazador directamente sobre las losas de granito del pavimento, como ocurre casi siempre en Galicia, donde el yeso es un material costoso. No se han hallado trazados de cantería en otros puntos del edificio; por tanto, nos encontramos con un ejemplo a medio camino entre las salas de trazas de las catedrales de españolas e inglesas y la práctica habitual de ejecutar las monteas en zonas apartados del tránsito (Figura 1).

La existencia y peculiar ubicación de las monteas se explica por la azarosa historia constructiva del edificio, que fue comenzado en 1769, pero no fue consagrado hasta 1803 , con varios parones de los trabajos y cambios en los canteros (13) (14) (15). Las trazas están relacionadas con la fachada de la iglesia, lo último en ser construido en el inmueble; todo indica que los maestros

\section{FULL-SCALE TRACINGS IN THE TRIBUNE OF THE CHAPEL OF SAINT TELMO IN TUI}

Since Classical Antiquity, full-scale tracings have been used in order to control the general layout of construction members and the shape of individual stonemasonry elements (1). In some occasions such drawings were placed just below the member that was being built; this allowed masons to control the dressing of the stones and, later on, to verify their correct placement; quite frequently, such tracings were executed in secluded places, such as rooftops, galleries or areas under stairways (2) (3) (9) (10). In other occasions, tracings were laid out in a dedicated room, known as tracing house or casa de la traza. In Mediaeval England, archival documents mention the trasura in Westminster Palace (4), while the tracing rooms in York Minster (5) (6) and Wells Cathedral (6) (7) and have been preserved. In Spain, the tracing houses in Seville (8) and Santiago de Compostela (9) (10) cathedrals are still extant, while there are documentary references to the ones in Granada cathedral (11) and the Monastery of El Escorial (12); all of them date from the Early Modern period.

In this paper, we shall describe and analyse a not-so-well-known example, the tracing room in the chapel of Saint Telmo in Tui, located in a raised tribune used as a choir (10). In spite of its small dimensions, 5.89 by 2.87 , a great number of lines are inscribed in the floor of the tribune, showing the stonecutting skills of the masons of Northwestern Spain. The tracings are executed directly on granite slabs, since the use of plaster, a costly material, is always scant in Galicia. No tracings have been found in other places in the building; thus, this example lies halfway between the tracing houses of Santiago, Seville, York or Wells and the usual practice of tracing in secluded places (Figure 1).

The tracings cannot be explained without a general understanding the complex building history of the chapel, that was not consecrated until 1803, after many changes in the working masons and interruptions of the works (13) (14) (15). As we shall see, the tracings are connected with the chapel's elevation, the last portion of the building to be constructed. This suggests that the masons sought the tribune as a quiet secluded space, protected from Galicia's lousy weather, to lay out their tracings when the building was almost finished; quite significantly, a tracing of a pediment has been found in the tribunes of Santiago cathedral, although the tracing 


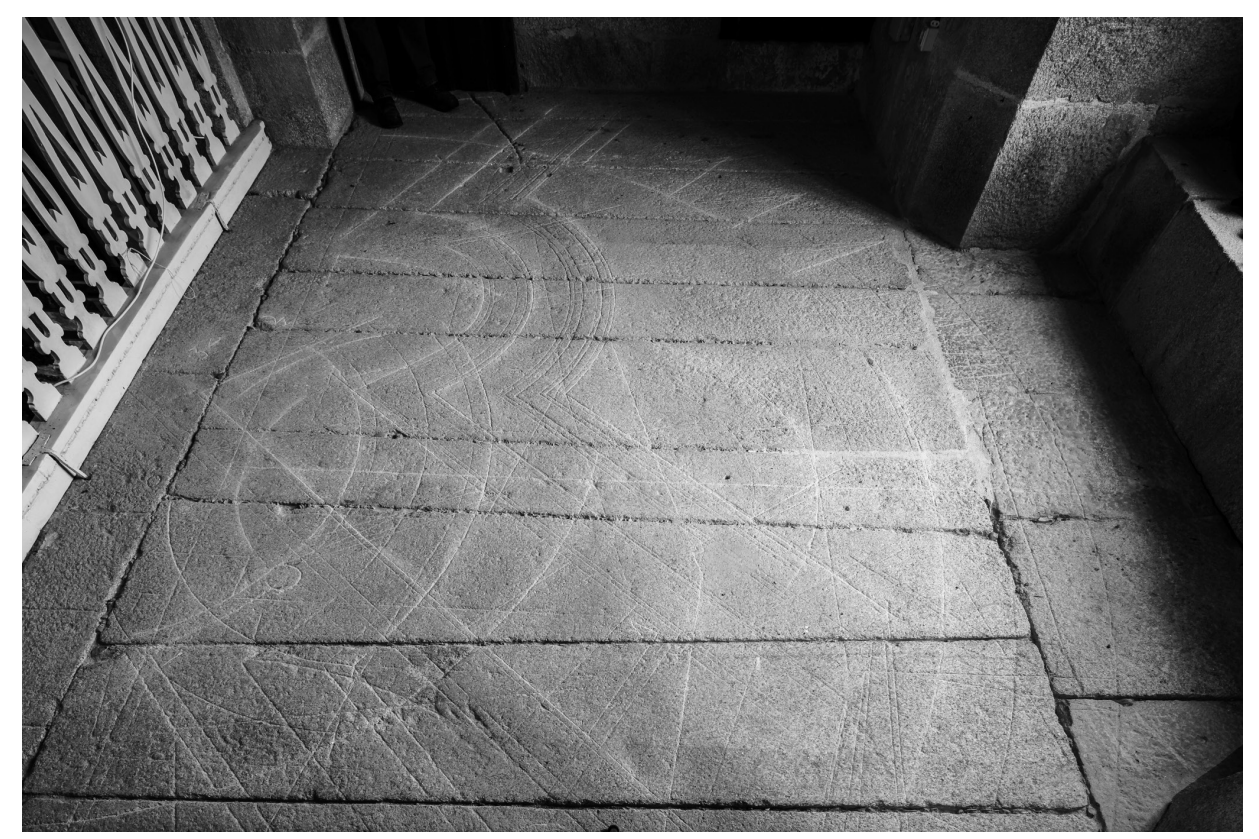

canteros de la obra se refugiaron a trabajar en el coro alto, cuando ya debía de estar construida la mayor parte de la iglesia, buscando un espacio marginal tranquilo y protegido de las inclemencias del tiempo, del mismo modo que en la Catedral de Santiago donde se ha localizado la montea de un frontón en el coro alto (10).

La capilla, Ilamada popularmente iglesia "do Corpo do Santo" por estar construida sobre la casa en la que vivió y falleció San Telmo en el siglo XIII, es un ejemplo sobresaliente de la implantación del barroco portugués en tierras gallegas. Su construcción comenzó bajo la dirección del arquitecto franciscano portugués fray Mateo de Jesús María en 1769, siguiendo su propia traza, bajo los auspicios del obispo tudense Juan Manuel Rodríguez Castañón, como sede de la Congregación de San Telmo de Niños Hijos de Vecino (16) (Figura 2). No parece que las monteas fueran realizadas por los maestros canteros Francisco Antonio Muiños, Juan Francisco Novás y Felipe Lopo, que firmaron un contrato el 17 de diciembre de 1776, para terminar de construir en tres años la iglesia siguiendo los planos de Fray Mateo; en aquel momento estaría ejecutado poco más que la cimentación (17) (18). En las condiciones del contrato se dice lo siguiente sobre la fachada: "que ha de Ilevar en cada esquinal del frontiespicio una torre con su escala correspondiente para su servicio, respectivamente, y para el coro que ha de llevar sobre la puerta principal; y las torres solamente han de subir hasta el alto y nivel de los costados, con las molduras necesarias y adornos precisos, a correspondencia de la frontera, por lo tocante a sus vasas, capiteles y cornizas, retirando cada torre lo que sea necesario para que house proper is located in another room, belonging to the present-day cathedral museum (10).

The chapel of Saint Telmo, an important example of the expansion of Portuguese Baroque in Galicia, is known in Tui as the church "of the body of the Saint", since it is built over the house where Saint Pedro González Telmo, confused in occasions with Saint Elmo, lived and died in the 13th century. Construction started under the direction of the Portuguese Franciscan architect Mateo de Jesús María in 1769, according to his own design, under the patronage of the bishop of Tui Juan Manuel Rodríguez Castañón, for the Congregation of Saint Telmo (16) (Figure 2). On December 1776, little more than the foundations was executed (17) (18). A contract was signed by stonemasons Francisco Antonio Muiños, Juan Francisco Novás and Felipe Lopo on December 17th, 1776, in order to finish in three years the building. Regarding the main elevation, the contract stipulates that "it must bear in each corner of the front a tower with a stair in order to give access to the tower itself and the choir that should be placed over the main door; and the towers should rise only to the level of the sides of the elevation, with the necessary mouldings and ornaments, with their bases, capitals and cornices in correspondence with the front of the elevation, setting back each tower as much as necessary to differentiate it from the front" (18). As we shall see, many of these elements are present in the tracings in the upper choir; however, the tracings in the choir do not seem to be executed in this moment. Although the accounts book of the works registers seven of the eight payments mentioned in the contract, construction was
1. Trazados de cantería en el coro alto de la capilla de San Telmo, Tui.

1. Stonecutting tracings in the tribune of the chapel of Saint Telmo, in Tui. 
2. Fachada de la capilla de San Telmo, Tui.

2. North elevation of the chapel of Saint Telmo, in Tui. haga diferencia de la frontera"(18). Si bien muchos de estos elementos aparecen en nuestros trazados y el libro de cuentas de la obra demuestra que se efectuaron siete de los ocho pagos comprometidos en el contrato, los trabajos nunca se concluyeron, al parecer por falta de caudales. Consta, por la documentación posterior, que dejaron sin cubrir la nave de la iglesia, para la que tenían previsto una cúpula, sin rematar la fachada y sin construir las dos torres (19). Así se explica que todavía no fuera posible utilizar el edificio el 15 de abril de 1785, cuando los cofrades solicitan licencia al cabildo para celebrar el día del santo en la capilla de San Telmo de la catedral porque "está por concluir la de el Cuerpo Santto" (20) (15).

El 11 de noviembre de 1790 se firma un nuevo contrato con el arquitecto Domingo de Novás y Lemos, natural de la parroquia tudense de Pazos de Reis, que intervendría también en reparaciones en la catedral de la ciudad a consecuencia de un rayo caído 1791, evitando una reconstrucción integral que nos hubiera privado de la catedral medieval; también dio en 1815 los planos de la iglesia de San Tomé de Parderrubias. En cualquier caso, en el contrato Novás se compromete a cubrir la capilla de San Telmo con una bóveda, posiblemente la actual, así como para terminar la fachada y remates del edificio, siguiendo una traza del propio Novás, que en el documento se compromete a estudiar la traza antigua y "formar otra que no desdiga en quanto sea posible de aquélla, pero de más moderado coste, suprimiendo o no continuando las dos torres que antes llevaba la primera obra, formando una sola en la frontera, que haga çimetría con ella en sus lavores y recortes" (21) (13) (14). El pliego de condiciones de obra anexo al contrato se indica que la nueva intervención no desentone con lo ya construido: "que todo el resto de la obra que está por hacer en la Capilla de San Thelmo se ha de procurar imitar en quanto sea posible a la que está echa en su frontera para que no desdiga la construcción de ésta con la de aquélla" (19). Así, se abandona la idea de las dos torres, se construye una sola en la calle central, que no se llega a acabar, y se termina la fachada principal, en aquel momento levantada hasta la altura del nicho de la imagen principal. En dicho pliego de condiciones se indica que el edificio está construido "hasta la metad del camarín en que ha de colocarse la ymagen de San Thelmo en el púlpito, y que falta éste por acabar del todo. Se ha de perfecionar y concluhir en lo que le reste con pulidez. Acabar con la misma y con arte la ymagen de dicho santo y colocarla en dicho camarín y púlpito con la maior seguridad", re- not completed, maybe by lack of financing. Other documents attest that the church nave, which was to be spanned by a vault, was left uncovered; also, the façade was left unfinished and the towers were not built (19). In fact, the building was still unusable on April 15th, 1785, when the members of the Congregation asked permission to the cathedral chapter to commemorate the day of the saint in the cathedral since "the church of the Body of the Saint is unfinished" (20) (15).

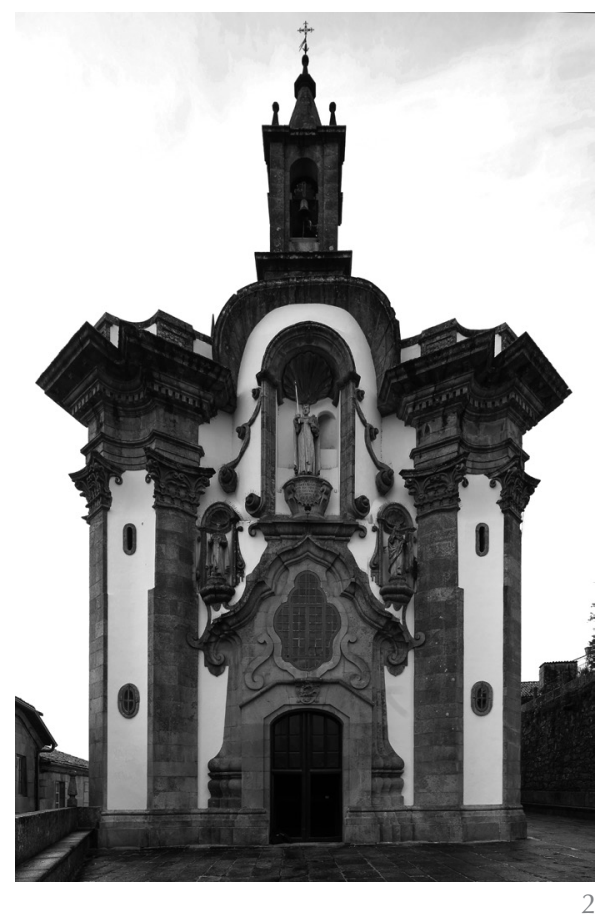

On November 11th, 1790, a new contract was signed with the architect Domingo de Novás y Lemos, born in Pazos de Reis, a small village near Tui. Later on, Novás refurbished the cathedral of Tui after a thunderbolt in 1791, avoiding a general transformation of the mediaeval cathedral; he also furnished the plans for the church of San Tome de Parderribas. Anyhow, the contract for the chapel of San Telmo stipulated that the church was to be spanned by a vault, quite possibly the present-day one, finishing at the same time the façade of the building following Novás' designs. In this document, Novás agreed to study the existing designs and "prepare another one that matches the old one, but with a smaller cost, not finishing the two towers that were included in the old designs, placing a single tower in the front, that keeps symmetry with [the existing section] in their ornaments" (21) (13) (14). The stipulations included with the contract make clear that at this moment the façade was finished up to the level of the recess that holds the image of the saint: "up to the half of the recess where the image of Saint Telmo in the preaching stand is to 
firiéndose, en nuestra opinión, al camarín del frente (21).

Tal como ha llegado a nuestros días, la fachada de la capilla se caracteriza por presentar paramentos curvos y planos en original combinación, jugando con la bicromía de los materiales: piedra granítica en soportes, marcos, molduras y elementos ornamentales, y blanco en los muros revocados. Cuenta con tres calles, presentando la central, mucho más ornamentada, la puerta de acceso y una ventana de trazado polilobulado, cobijadas por un arco mixtilíneo y enmarques sobrepuestos. Sobre ambas se dispone el nicho del santo titular del templo, concebido a modo de camarín, con acceso desde el interior del edificio para atender la imagen del santo, como mínimo los días de su fiesta, si bien la estatua actual data de 1872. También existen dos hornacinas secundarias, más pequeñas, con las imágenes de Santo Domingo de Guzmán y San Vicente Ferrer, santos de la orden dominica como San Telmo.

Remata el conjunto un arco de peculiar despiece, con forma de cofia o peineta ( $\mathrm{Fi}$ gura 3), Como veremos, uno de los trazados del coro alto parece estar concebido para controlar su ejecución, si bien la coincidencia entre uno y otro no es total. Se trata de un arco abocinado en torre redonda, un tipo arquitectónico presente en el tratado de cantería de Tomás Vicente Tosca (22) o los manuscritos de Ginés Martínez de Aranda (23) y Juan de Portor y Castro (24) (Figura 4) o en el de Alonso de Vandelvira (25), donde aparece como "Tronera redonda". Ahora bien, estos modelos se interpretan aquí de forma muy libre, pues en lugar de soportar el muro, como es habitual, el arco hace las veces de visera o cornisa; en segundo lugar, el encuentro con el muro no responde exactamente a la curva de intersección entre dos cilindros, puesto que el trazado del arco no es circular sino oval, y be placed" (21); they also stress that the new construction should match the existing one: "... the new works that is to be made in Saint Telmo's Chapel should be similar to the existing work in its front, so that it matches it" (19). That is, the twin towers of the 1776 contract are replaced by a single central tower in Novás' project.

Anyhow, this single tower was never built. In its present-day state, the façade of the chapel includes curved and planar surfaces in a peculiar combination; it uses granite for pilasters, window frames, mouldings and ornamental elements, and whitewash in the walls. It features three sections; the central one, with much richer decoration, includes the access door and a complex window. Over the window stands a recess for an image of the Saint, which allowed changing the garments of the saint on the day of his holiday; however, the present-day image dates from 1870. There are also two secondary recesses, holding the images of Saint Dominic of Guzmán and Saint Vincent Ferrer, two saints of the Order of Preachers, just as Saint Pedro González Telmo.

Over the main recess, a peculiar arch is placed (Figure 3); as we shall see, one of the tracings in the tribune is connected with it. It is a splayed arch placed on a curved wall or "Arco abocinado en torre redonda", an architectural type that is present in the treatise of Tomás Vicente Tosca (22) or the manuscripts by Ginés Martínez de Aranda (23) and Juan de Portor y Castro (24) (Figure 4) or the one by Alonso de Vandelvira (25), where it is named as "Tronera redonda". However, the interpretation of such models in Tui is remarkably free in a number of aspects. Instead of supporting the wall, as usual, the arch projects from it in the fashion of a cornice; the intersection of the arch and the wall is not the usual intersection of two cylinders, since the directrix of the arch is not a half-circle, but rather a peculiar oval,
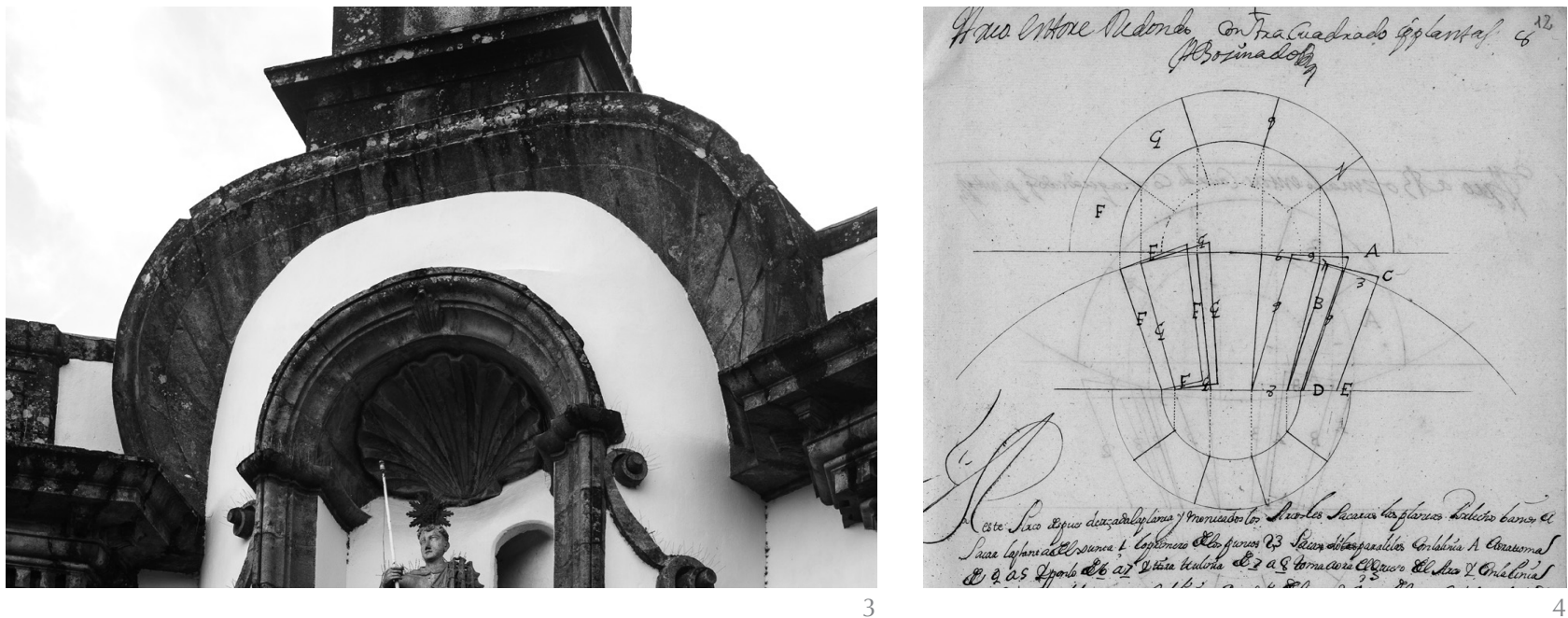

3. Fachada de la capilla de San Telmo, Tui. Detalle del arco central.

3. North elevation of the chapel of Saint Telmo, in Tui. Central arch

4. Arco abocinado en torre redonda. Juan de Portor y Castro, Cuaderno de Arquitectura, 1708

4. Splayed arch opened in a convex wall. Juan de Portor y Castro, Cuaderno de Arquitectura, 1708. 
el borde exterior se aparta todavía más del trazado teórico; por último, la disposición de las juntas de intradós tampoco sigue el esquema habitual, basado en el empleo de generatrices de un cono.

Todo parece indicar que el cilindro de la calle central, hoy rematado por el citado copete, es en realidad el arranque de la torre diseñada ahora en 1790, la cual debió de ser pensada con mucha más altura, sobresaliendo abundantemente sobre el caserío de la ciudad, pues se pensaba decorar con un reloj o un escudo, nunca realizados, "que en el sitio donde en la nueba planta se figura el mostrador de un relox se ha de colocar un escudo de buena piedra, y corpulento, a proporción de la altura y ancho de la obra; que en su buque o capacidad contenga dos quarteles divididos de alto avajo, en uno una media luna y en otro tres estrellas, con su corona en lo alto y superficie de dicho escudo que lo cubra todo, y vien voladiza, corpulenta y a proporción; y por los costados de aquél, con lazadura independente desde su inferioridad, dos ramos de follage airosos, que le sirva de adorno con proporción a lo todo de la obra" y también con otros elementos citados en las condiciones de obra "que las piedras de el pectoril del balcón de la torre han de ser enterizas, sin otra emienda más que en los quatro esquinales donde a tizón unirán, y aseguradas con gatas de fierro bien emplomadas; y los pirámides que la planta demuestra en el balcón y lo más de dicha torre se han de asegurar y fijar macheembrados; y siendo precisa para su maior firmeza alguna gata de codillo de fierro, se la ha de poner también emplomada" (21). En cambio, las dos calles laterales de la fachada son en realidad los macizos del primer cuerpo de las dos torres de fray Mateo que nunca se llegaron a terminar de construir, articulados por medio de dos gigantescos pilastrones corintios dispuestos en ángulo, cerrando un muro cóncavo, que comparten un movido y quebrado entablamento. Las monteas del coro se deben a este momento en que por fin se va a terminar definitivamente el edificio, donde hay necesidad de analizar lo ya construido y de decidir cómo rematar la fachada, que, como hemos visto, tampoco se terminó según lo concertado.

\section{LEVANTAMIENTO Y ANÁLISIS DE LAS MONTEAS Y LA FACHADA}

En otros casos similares (9) (10) (26), los autores de este trabajo han realizado levantamientos de trazados de cantería mediante calco manual directo o bien mediante toma de los puntos clave del trazado mediante estación total láser. Sin embargo, en este caso el elevado número de líneas super- and the outer edge of the arch departs even more from the theoretical tracing; also, the placement of bed joints does not follow the usual scheme, based in the generatrices of a cone.

Quite possibly, the cylinder in the central portion is in fact the starting section of the single tower planned in 1790, that was to be given much more height, rising over the houses of the city, since it was planned to be decorated with a church or coats of arms, that were never executed, since "in the place where in the designs include a clock, a coat of arms dressed in good stone should be placed, quite large, in proportion with the width and height of the new construction; it should include two quarts divided from top to bottom, including a half moon on the first one and three stars in the other one, with a crown above over everything, projecting in proportion; and at the sides, ... two bunches of leaves, as ornament in proportion with the rest of the construction" and "the stones in the front of the balcony in the tower should be whole stones, without no features except for the four corners where they should be joined with iron staples filling the cracks with lead; and the pyramids in the design show the balcony and the parts of this tower that should be fastened...; and if there is neccesary, iron L-shaped staples should be placed, filling the cracks with lead" (21). As for the outer sections, they are really the basements of the unfinished towers designed by Mateo de Jesús María, articulated by two huge Corinthian corner pilasters, at the ends of a concave wall, joined by a crooked entablature. The present-day bell-tower is a disgraceful modern addition. The tracings in the upper choir belong to this stage when the building is to be finished at last; it is necessary to analyse what has been done up to this moment and decide how the elevation should be finished, although, as we have seen, it was not finished according to this contract.

\section{SURVEY AND ANALYSIS OF THE TRACINGS AND THE FAÇADE}

In other similar occasions, the authors have carried on surveys of full-scale stonecutting drawings tracing them directly on paper or using a laser total station (9) (10) (26). However, in this occasion, the high number of lines packed in a small space made the use of these methods unreliable. Taking this into account, we have taken five digital photographs of the tracings, usign a Canon 5D Mark II 21 Mpx camera and a TS-E 17 $\mathrm{mm} \mathrm{f/4} \mathrm{lens,} \mathrm{mounted} \mathrm{on} \mathrm{a} \mathrm{photographic}$ tripod, in order to rectify them afterwards. It has not been possible to take photographs 
puestas en un pequeño espacio desaconsejaba el empleo de estos métodos. Por tanto, se han tomado cinco fotografías digitales de los trazados empleando una cámara Canon 5D Mark II, de 21 Mpx y un objetivo TS-E $17 \mathrm{~mm} \mathrm{f} / 4$, montado sobre trípode fotográfico. No ha sido posible tomar fotografías con el eje del objetivo en posición vertical, puesto que la rótula y patas del trípode hubieran ocultado elementos del trazado; también se ha desestimado la posibilidad de emplear la columna del trípode en posición horizontal, puesto que este método hubiera exigido un número excesivo de fotografías, lo que haría muy difícil referenciarlas posteriormente entre sí. Por tanto, se ha buscado obtener la mayor altura posible sobre el pavimento, empleando la columna central del trípode en su posición habitual y descentrando el objetivo objetivo TS-E para evitar en lo posible la presencia de elementos perturbadores en la imagen. Se ha empleado el sistema de visión directa o Live view que ofrece la cámara con objeto de controlar con facilidad el encuadre y descentramiento; este sistema permite enfocar manualmente con muy alta precisión, ampliando hasta diez veces la imagen recogida por el sensor. Como ventaja añadida, el sistema Live view bloquea automáticamente el espejo de la cámara, lo que evita la vibración producida por la subida del espejo; también se ha empleado con este fin un disparador de cable.

Con objeto de referenciar posteriormente las fotografías, se han tomado coordenadas de puntos significativos del pavimento, en concreto encuentros de bordes de baldosas, mediante una estación total Leica Leica TCRM 1205. En gabinete se han calcado los trazados desde las fotografías mediante el programa AutoCAD 2010, obteniendo cinco archivos vectoriales Dado que se conocían las coordenadas de los puntos de cruce de las baldosas, estos archivos vectoriales se han sometido posteriormente a una transformación homográfica mediante el programa Homograf 2002, con objeto de obtener una proyección ortográfica sobre el plano del pavimento del coro (Figura 5).

Adicionalmente, se ha realizado un levantamiento de los elementos de la fachada que podrían corresponder a los trazados, mediante técnicas bien probadas por los autores en otros trabajos anteriores (27) (28) (29) y empleando la misma estación total. ${ }^{1}$

Partiendo de estos dibujos, un examen detenido de la montea permite distinguir al menos seis grupos de líneas. Existe en primer lugar un gran arco de medio punto con juntas de lecho (Figura 6). Otras trazas de with the axis of the lens in vertical direction, in order to show the tracings in true shape, since in this case the head and the legs of the tripod would have gotten in the way, hiding vital elements in the tracing. It was also impractical to place the tripod column in horizontal position, since this technique would have lead us to a high number of photographs, making its referencing and rectification quite difficult. Thus, our aim has been to raise the camera over the floor as much as possible, using the tripod column in its ordinary position, taking oblique photographs and employing also the shift feature of the TS-E lens in order to prevent the legs of the tripod from hiding essential elements of the tracing. We have used also the "Live view" feature of the camera in order to control the framing and de-centering of the lens. Besides, this feature allows high-precision manual focusing, since the image in the rear screen of the camera can be enlarged up to ten times. As an added advantage, Live View shooting involves automatic mirror lock-up, in order to prevent vibration, which may have affected the sharpness of the images; a cable release has also been used with this purpose.

At the same time, the coordinates of a number of key points in the flooring, in particular slab corners, have been taken with a Leica TCRM 1205 laser total station in order to reference and rectify the photographs. In the office, we have traced the drawings from the photographs using AutoCAD 2010, getting five vector files. Since the coordinates of a number of key points in the photographs were known, these files have been subject to homographic transforms using the program Homograf 2002 in order to get an orthographic projection of the tracings on the plane of the tribune floor (Figure 5).

At the same time, we have carried on a topographical survey of the members in the façade of the church that may correspond with the tracings, using a number of techniques that the authors have employed in a number of previous studies (27) (28) (29) using the same laser total station. ${ }^{1}$

Starting from those drawings, a detailed inspection has lead us to classify the lines in the tracing in six groups. There is a large round arch, with a number of bed joints (Figure 6) and a number of smaller arches and two rectangles, that are placed symmetrically around the axis of the larger arch, but do not share the same centre (Figure 7). There are also two groups of mouldings; the first one includes two straight portions placed at an obtuse angle,
1 Los elementos de la fachada que podrían corresponder a los trazados, como el arco principal, la cornisa al nivel de los arranques del arco y el nicho que alberga la imagen de San Telmo se han levantado mediante la misma estación total, lo que ha permitido obtener un archivo de coordenadas y dibujar las cornisas y la cofia mediante AutoCAD 2012, con objeto de comparar los trazados con la obra construida (Figuras 12, 15)

${ }^{1}$ The elements in the chapel front elevation that may correspond with the tracings, in particular the main arch, the cornice at the level of its springers and the recess with the image of Saint Telmo have been surveyed also with the same laser total station. This has allowed us to gather a coordinate file allowing to get precise plans and elevations of the arch and the cornices in AutoCAD 2012 (Figure 5), in order to compare the tracings and the built members (Figures 12, 15). 
5. Trazados de cantería en el coro alto de la capilla de San Telmo, Tui. Levantamiento por rectificación fotográfica. Trazados en línea media. Sección de los muros en línea gruesa. Pavimento en línea fina.

5. Stonecutting tracings in the tribune of the chapel of Saint Telmo, in Tui. Survey prepared using homographical transforms. Wall sections in thick lines. Tracings in half-weight lines. Floor joints in thin lines.

6. Trazas de un arco en el coro de la capilla de San Telmo, Tui. Otras trazas del coro en línea de puntos.

6. Tracings for a large arch in the tribune of the chapel of Saint Telmo, in Tui. Other tracings in dotted lines.

7. Trazas coaxiales con el arco central en la capilla de San Telmo, Tui, en línea gruesa. Otras trazas del coro en línea de puntos.

7. Tracings for a small arch or recess in the tribune of the chapel of Saint Telmo, in Tui. Other tracings in dotted lines. arcos y dos rectángulos se disponen simétricamente alrededor del eje del arco mayor, pero no son concéntricas con este; en estos arcos no se aprecian juntas de lecho (Figura 7). Aparecen también dos series de molduras, una de ellas formada por dos directrices rectas unidas por una línea cóncava (Figura 8), y otra que sugiere un vano (Figura 9). Se puede reconocer una serie de líneas dispuestas en abanico, con transversales en los extremos (Figura 10), y existe por último un numeroso grupo de marcas aisladas que no se pueden agrupar en formas reconocibles (Figura 11). joined by a curved section (Figure 8), while the other group of mouldings suggests the frame of a door (Figure 9). There are also a number of lines placed as a fan, with transversal lines at one end (Figure 10); last, there are also a remarkable number of isolated lines that cannot be grouped in meaningful shapes (Figure 11).

Starting with the first two groups, we can overlay the larger arch with bed joints and the small arch on the façade elevation (Figure 12). The greater arch matches the dimensions of the main arch of the façade

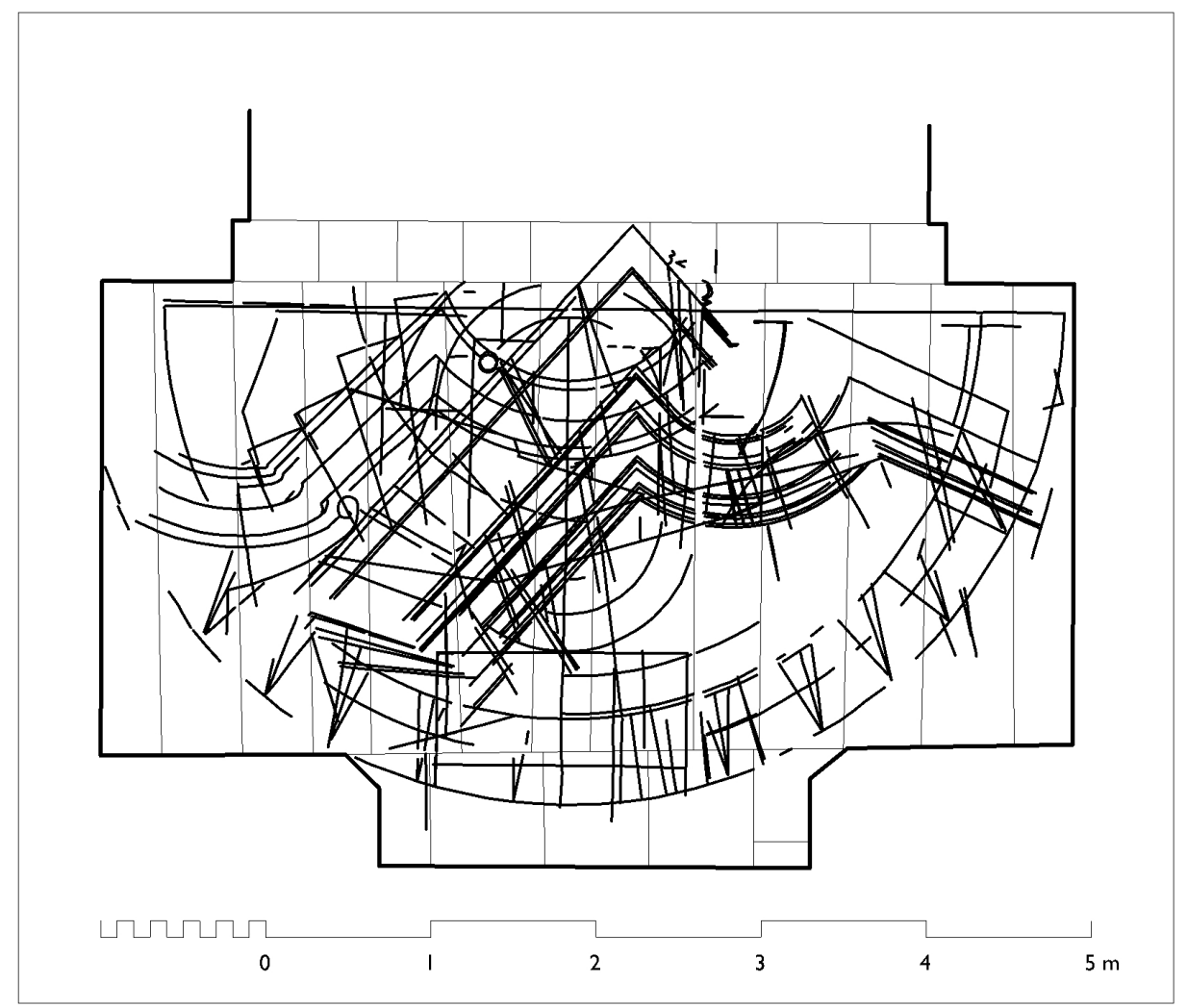

5
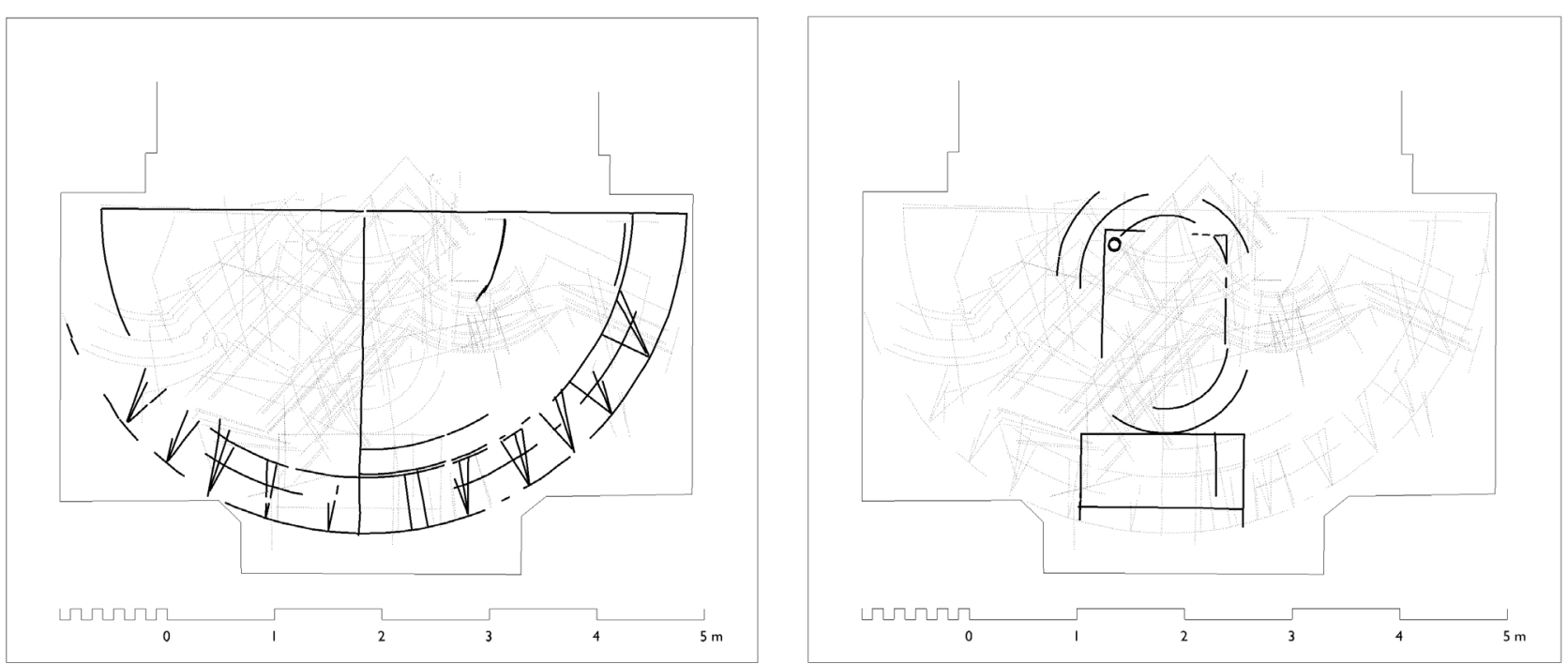
Empezando por los dos primeros grupos, podemos superponer al levantamiento de la fachada el gran arco de medio punto con juntas de lecho (Figura 12). Se observa que el arco mayor se aproxima en dimensiones a la cofia o visera central de la fachada; ahora bien, la coincidencia no es exacta, puesto que la proyección del arco sobre un plano vertical perpendicular a su plano de simetría muestra un trazado apreciablemente rebajado, mientras que la montea del coro se aproxima mucho a un arco de medio punto.

Resultan especialmente Ilamativas unas líneas dispuestas en la montea a modo de juntas de lecho del arco mayor, dispuestas en grupos de dos o tres juntas que se encuentran entre sí en el trasdós del arco. Prolongando estas líneas (Figura 13), se observa que algunas de ellas concurren con precisión aceptable en el centro del arco; es decir, en algún momento se pensó en emplear un trazado habitual en este tipo de arcos, disponiendo las juntas de lecho como un haz de planos que tiene por recta común el eje del cono que define el intradós del arco.

El resto de las líneas que parten del trasdós del arco son de interpretación más difícil. Admitiendo unas tolerancias relativamente generosas, muchas de ellas parecen dirigirse al punto situado en la intersección del plano de simetría del arco con la prolongación del trasdós del arco. Este punto está situado fuera del coro alto, por lo que los autores del trazado hubieron de emplear, bien un andamio que les permitiera fijar una cuerda a un punto situado fuera de la tribuna, bien un método indirecto para trazar estas juntas de lecho por un punto que no podían materializar; en cualquiera de los casos, esto puede justificar tolerancias approximately; however, the match is not exact, since the projection of the built arch shows a clearly surbased directrix, while the tracing approximates closely a round arch.

The lines representing bed joints in the larger arch are rather striking. They are grouped in bunches of two or three lines, starting from the same point in the arch extrados. Extending these lines (Figure 13), it is easy to tell that there is a family of lines that meet, with reasonable precision, in the center of the arch. That is, in some moment in the process, the masons were meaning to employ a wellknown construction, placing bed joints as a number of planes passing through the axis of the cone that is materialised by the arch intrados.

It is not so easy to interpret the remaining lines starting from the arch extrados. If we accept rather loose tolerances, a number of these lines seem to be traced through the intersection of the symmetry plane of the arch with the extension of the extrados circumference of the arch. This point is outside the tribune; thus, the masons should have used either a frame supporting a nail that allowed fixing a rope to this point outside the tribune, or either an indirect method allowing the tracing of a line passing through a point outside the reach of the masons; both hypotheses justify the consideration of tolerances in the range of some centimetres. The third group of lines meet approximately in two points, also in the extrados circumference of the arch, placed symmetrically at both sides of the centre plane of the arch. Once again, both points are placed outside the edge of the tribune, justifying tolerances around $5 \mathrm{~cm}$.
8. Trazado de cornisa en el coro de la capilla de San Telmo, Tui. Otras trazas del coro en línea de puntos.

8. Tracings for a cornice in the tribune of the chapel of Saint Telmo, in Tui. Other tracings in dotted lines.

9. Posible trazado de las molduras que encuadran la puerta de acceso y la ventana del coro en la capilla de San Telmo, Tui, en línea gruesa. Otras trazas del coro en línea de puntos.

9. Tracings for window mouldings and cornice in the tribune of the chapel of Saint Telmo, in Tui. Other tracings in dotted lines.

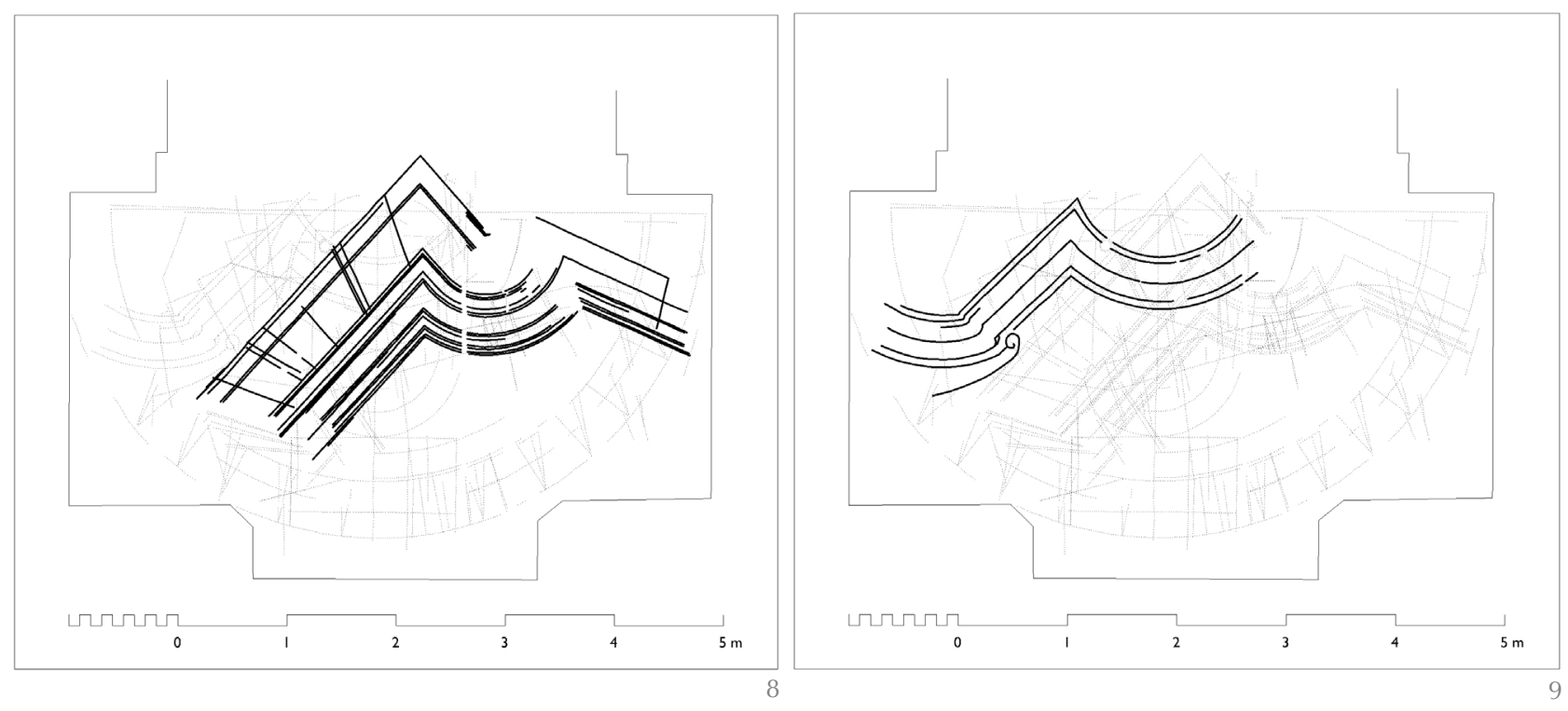


10. Posible trazado de desarroIlo de plantillas en la capilla de San Telmo, Tui, en línea gruesa. Otras trazas del coro en línea de puntos.

10. Tracings for stonecutting templates in the tribune of the chapel of Saint Telmo, in Tui. Other tracings in dotted lines.

11. Trazas aisladas en la capilla de San Telmo, Tui, en línea gruesa. Otras trazas del coro en línea de puntos.

11. Unidentifiable tracings in the tribune of the chapel of Saint Telmo, in Tui. Other tracings in dotted lines. de algunos centímetros. Lo mismo se puede decir de las restantes líneas que ocupan la posición de las juntas de lecho: convergen aproximadamente en dos puntos situados en la circunferencia de trasdós del arco, dispuestos simétricamente a ambos lados del plano medio del arco; una vez más, ambos puntos caen fuera del coro alto, lo que justifica unas tolerancias que no sobrepasan $5 \mathrm{~cm}$.

Esto parece indicar que los autores del trazado realizaron tres tanteos diferentes para el trazado de las juntas de lecho del arco mayor: el primero con un centro coincidente con el centro del arco; el segundo, con un centro dispuesto en la circunferencia de trasdós y el tercero con dos centros dispuestos simétricamente a ambos lados del plano medio del arco. Las tres soluciones se pueden encontrar con relativa facilidad en los trazados y manuscritos de cantería (23), pero finalmente los ejecutores de la capilla no pusieron en práctica ninguna de ellas, sino una solución peculiar que emplea un trazado oval del arco y planos de lecho inclinados en los riñones y prácticamente verticales en la proximidad de la clave.

Todo esto lleva nuestra atención al grupo de líneas dispuestas en abanico, que recuerdan los desarrollos de plantillas de intradós habituales en muchos tratados y manuscritos de cantería (25) (30) (Figuras 10, 14). Estos desarrollos, resueltos en muchos casos por triangulación, y con menor frecuencia por abatimiento, pretendían obtener en verdadera forma y magnitud el cuadrilátero definido por los vértices de intradós de las dovelas de piezas de cantería, en particular arcos. Podría tratarse de las plantillas de intradós de uno de los sucesivos tanteos para el arco mayor de la fachada, si bien el estado fragmentario de esta parte del trazado
All this suggests that the masons that executed the tracing made three trials for the tracing of the bed joints of the larger arch. In one of them, they used bed joints passing through the centre of the arch; in another one, they traced the joints so that they went through the intersection of the intrados circumference and the symmetry plane of the arch; and in another alternative, they used two different centres, placed symmetrically at both sides of the central plane. All three solutions can be found easily in stonecutting treatises and manuscripts (23). However, finally the masons eschewed all three methods for a peculiar solution that uses an oval directrix for the arch, strongly slopping bed joints near the springers and almost vertical ones in the vicinity of the keystone.

All this brings our attention to the fanshaped group of lines, which remind the templates in some stonecutting treatises and manuscripts, based on polyhedral developments (25) (30) (Figures 10, 14). Such developments, solved usually through triangulation and not so frequently by rabattements, were used to determine the true size and shape of the quadrilateral formed by the corners of the intrados face of a voussoir of a masonry member, in particular arches. So, the fan-shaped lines could represent the intrados templates corresponding to one of the trials for the main arch, although the fragmentary state of these lines prevents us to arrive to more precise conclusions.

As we have said before, the tracings include also a group of lines in the shape of a cornice, with two straight sections and a concave portion joining them (Figure 8). Overlaying these lines with the plan of the cornice placed in the façade at the level of
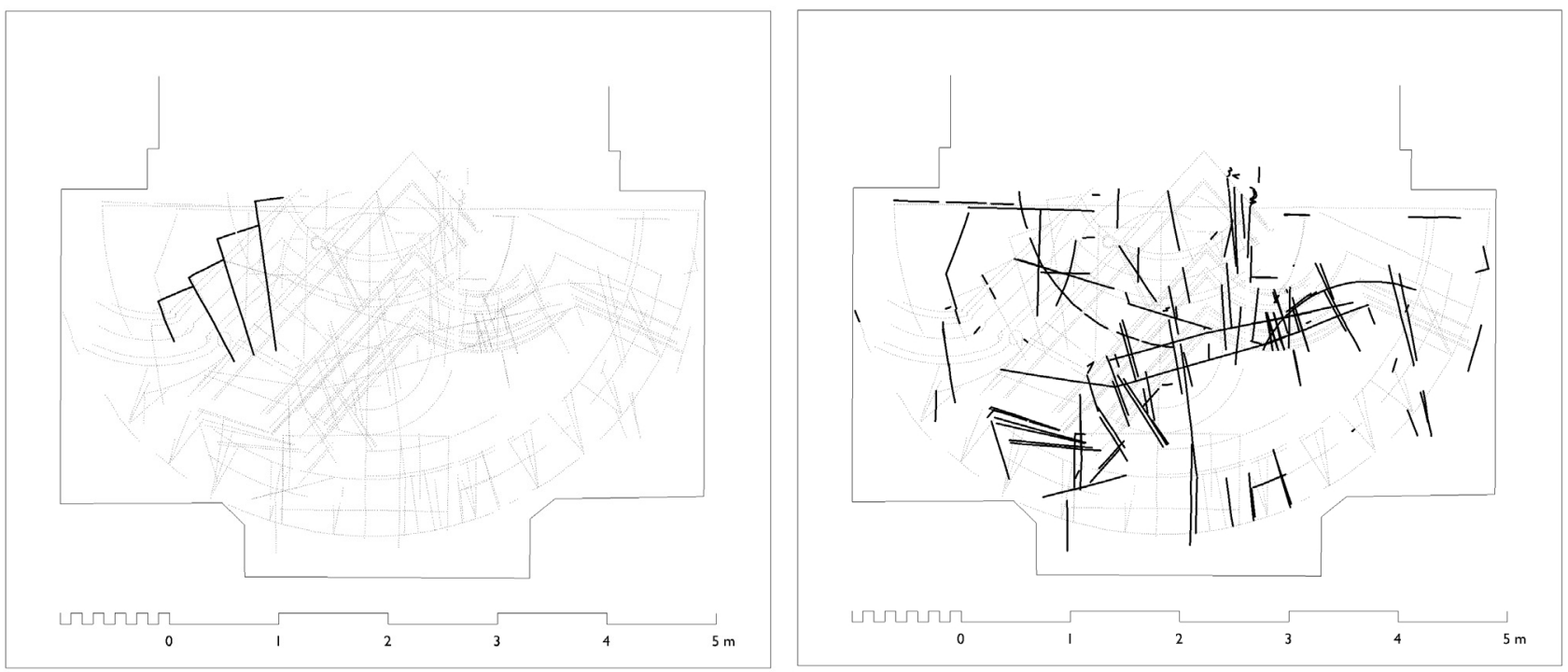
impide determinar el método concreto empleado en su construcción.

Como hemos dicho, la montea incluye también un grupo de líneas que parecen representar una cornisa, con dos grupos de molduras rectas y un grupo de líneas cóncavas uniendo las anteriores (Figura 8). Superponiéndolas con la planta de la cornisa de la iglesia dispuesta a la altura de las impostas del arco central (Figura 15), se observa que montea y obra construida coinciden con precisión aceptable.

En el cuarto de los grupos de líneas que hemos mencionado (Figura 9) existe un grupo de líneas cóncavas que corresponden a una solución alternativa de la cornisa; ahora bien, en uno de los extremos encontramos una representación parcial de una puerta o ventana, con una voluta en la esquina superior. Si bien el trazado no coincide estrictamente con los elementos construidos de la fachada, la presencia de una voluta recuerda claramente el marco que encuadra la puerta de acceso y la ventana del propio coro. Por tanto, este grupo de líneas parece corresponder a un primer tanteo para la cornisa, que después se reutiliza para estudiar una solución para la ventana del propio coro, que tampoco se pone en práctica finalmente. Por otra parte, podemos entender que las trazas coaxiales con el arco mayor, con dos arcos simétricos entre sí, corresponden al peculiar diseño de las ventanas dispuestas en los paños laterales de la fachada, si bien la coincidencia no es exacta (Figuras 7, 2). the springers of the large arch (Figure 15), it fits rather closely.

The fourth group of lines (Figure 9) includes a number of concave lines that may correspond to an alternative solution for the cornice; at the other end of these lines there is a portion of the framing of a door, with a volute in the upper part. Although this tracing does not fit exactly the built members in the façade, the volute reminds the frame around the entry door and the window of the upper choir. Thus, this group of lines may correspond to a solution for the cornice that was not used and was reused later for a trial for the choir window, also unused. Also, the tracings that share their axis with the great arch may represent the peculiar windows at the sides of the façade, although again the coincidence is not exact (Figures 7, 2).

\section{CONCLUSIONS}

To summarize, the combined analysis of the tracings, archival documentation and the built structure furnishes a first-hand vision of the construction processes put forward in order to build the chapel that none of this sources can offer in its own. In particular, the lack of exact correspondence between the central arch and its tracing, together with the three tentative schemes for its bed joints, or the differences between the drawn doors and the executed ones show clearly the uncertainties and doubts that surrounded the construction of Saint Telmo's chapel, that are also attested by archival documentation, although from another point of view. As we have seen, the initial plan included two towers placed at both flanks of the main elevation of the
12. Trazas de un arco en el coro de la capilla de San Telmo, Tui, en línea fina, superpuestas al levantamiento del arco central de la fachada, en línea gruesa.

12. Tracings for a large arch in the tribune of the chapel of Saint Telmo, in Tui, in thin lines, overlaid with a survey of the central arch in the North façade, in thick lines.

13. Trazas del arco central de la fachada de la capilla de San Telmo, Tui, en línea gruesa, con prolongación de las juntas de lecho por tres métodos, en línea de trazos, puntos y trazos y puntos.

13. Tracings for a large arch in the tribune of the chapel of Saint Telmo, in Tui, in thick lines, with extensions of the bed joints by three different methods, in dashed, dotted and dash-dot lines.
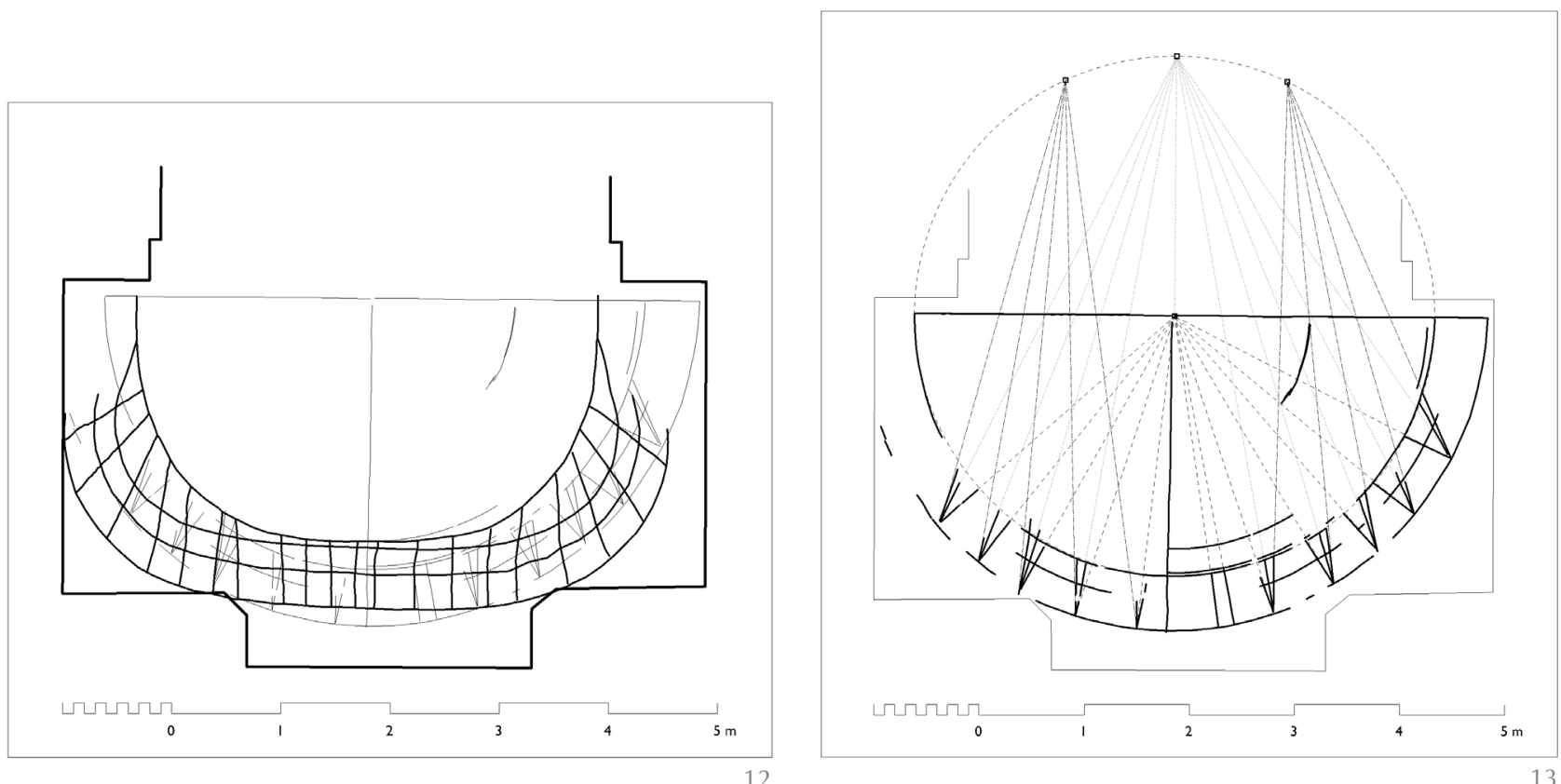
14. Desarrollo de las plantillas de la "Tronera redonda de círculo entero". Alonso de Vandelvira, Libro de trazas de cortes de piedras, c. 1585.

14. Stonecutting templates for a splayed opening, constructed by developments. Alonso de Vandelvira, Libro de trazas de cortes de piedras, c. 1585 .

\section{CONCLUSIONES}

Por todo lo anterior, el análisis conjunto de la montea, la documentación de archivo y la materialidad de la propia obra nos ofrece una visión de primera mano, casi diríamos una radiografía, de los procesos de ejecución de la obra, que todas estas fuentes no pueden ofrecer por separado. En concreto, la falta de coincidencia exacta entre la $\mathrm{CO}^{-}$ fia y su trazado, junto con los tres tanteos para la orientación de sus juntas de lecho, o las diferencias entre la ventana dibujada y la construida nos hablan de las numerosas dudas y cambios de planteamiento a lo largo de la obra, que se pueden seguir desde otro punto de vista en la documentación de archivo. Hemos visto que en un primer momento se piensa disponer dos torres a ambos lados de la fachada, a las que se renuncia en favor de una torre única en la tradición portuguesa, lo que da lugar al paramento curvo sobre el que se dispone la cofia, que tampoco se termina. También hemos visto cómo los detalles reflejados en la documentación pueden variar sobre la marcha; por ejemplo, se cambian los relojes por escudos del comitente. No tiene nada de extrañar que la obra ejecutada coincida en algunos aspectos con los trazados y los proyectos en papel, pero se distancie de ellos en muchos otros detalles. Estos cambios de planteamiento son frecuentes en otras obras de la Edad Moderna para las que se han haIlado trazados de cantería (28) (31). Todo esto debería ponernos en guardia contra interpretaciones simplistas de los procesos de diseño y ejecución de la arquitectura de la Edad Moderna. Es cierto que los tratados y manuscritos influyen en planos y trazados, pero no siempre de forma literal; y a su vez, los dibujos y monteas se realizan para dirigir la ejecución de la obra, pero raras veces se siguen estrictamente.

\section{AGRADECIMIENTOS}

Este trabajo forma parte del Proyecto de Investigación "Construcción en piedra de cantería en los ámbitos mediterráneo y atlántico" (BIA2009-14350), financiado por el Ministerio de Economía y Competitividad del Gobierno de España, en el contexto del Plan Nacional de $\mathrm{I}+\mathrm{D}+\mathrm{i}$ y el proyecto "Documentación y análisis de los trazados de cantería de la catedral de Murcia" de la Fundación Séneca. Los autores desean agradecer a la Cofradía de San Pedro González Telmo y a la familia Vila las facilidades ofrecidas para la toma de datos en la Capilla de San Telmo de Tui. chapel; later on, these towers are left out for a single tower in the Portuguese tradition, materialising the convex front from which the large arch projects, although this single tower was not finished. We have seen also that the details depicted in paper can change also; for example, a coat of arms substitutes the clock. It is only natural that built members follow in some cases tracings and drawings on paper, but depart from them in other occasions. Such on-the-fly decisions were are also relatively frequent in other constructions in Baroque Spain (28) (31). All this should warn us against simplistic interpretations of design and execution processes in Early Modern architecture. Of course, treatises and manuscripts influence designers and builders, and their solutions reflect in drawings and tracings, but not always in a literal fashion; on their turn, drawings and tracings are not always followed strictly in actual construction, and in particular, many trials and changes may happen before construction is finished.

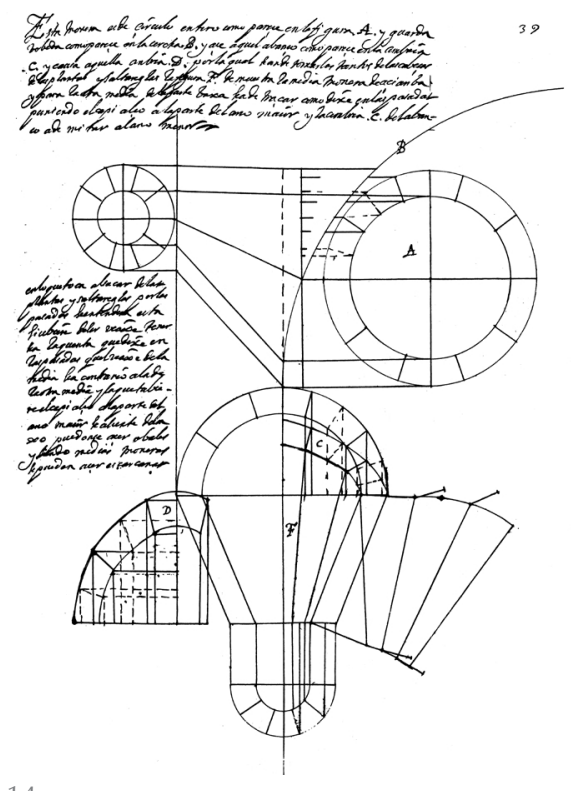

14

\section{ACKNOWLEDGEMENTS}

This study is funded by the Research Proyect "Stonecutting in the Mediterranean and Atlantic Areas" (BIA2009-14350), sponsored by the Ministry of Economy and Competitiveness of the Spanish Government, in the frame of the National R+D Plan, and by the project "Documentacion y analisis de los trazados de canteria de la catedral de Murcia", sponsored by Fundacion Seneca. The authors wish to thank the Brotherhood of Saint Pedro Gonzalez Telmo and the Vila family their help during the survey of the Chapel of Saint Telmo. 


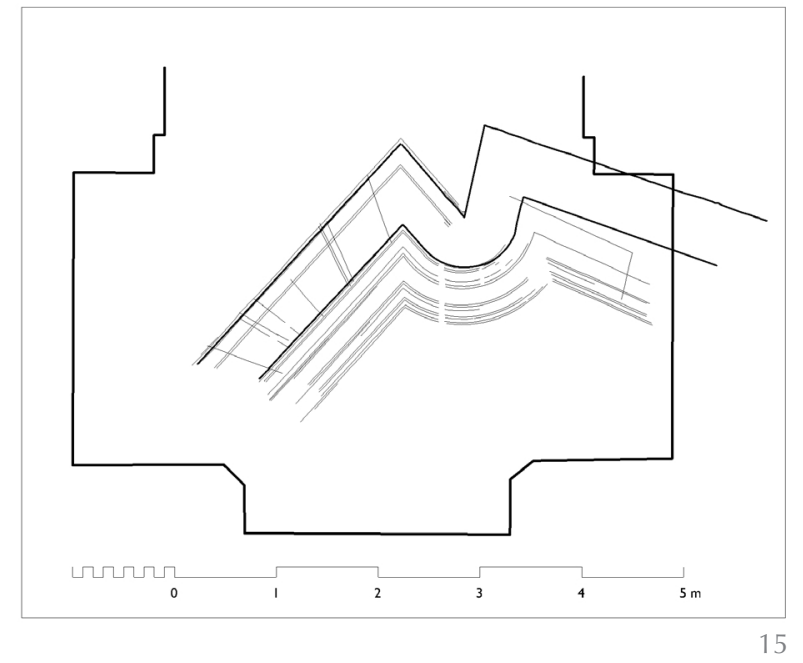

15
15. Trazado de cornisa en la capilla de San Telmo, Tui, en línea fina, superpuesto a la cornisa superior de la fachada, en línea gruesa.

15. Tracings for a cornice in the tribune of the chapel of Saint Telmo, in Tui, in thick lines, overlaid with a survey of the cornice in the North façade, in thick lines.

\section{REFERENCIAS / REFERENCES}

(1) Haselberger, L. (1983): "Die Bauzeichnungen des Apollontempels von Dydima". Architectura, Vol. 13, no. 1, 13-26.

(2) Ruiz de la Rosa, J.A. (2007): “Dibujos de ejecución. Valor documental y vía de conocimientos de la catedral de Sevilla". In La catedral gótica de Sevilla. Fundación y fábrica de la obra nueva. Universidad de Sevilla, Sevilla, 297-348.

(3) Ruiz de la Rosa, J.A., Rodríguez Estévez, J.C. (2002): "Capilla redonda en vuelta redonda' (sic): Aplicación de una propuesta teórica renacentista para la catedral de Sevilla". In IX Congreso Internacional Expresión Gráfica Arquitectónica. Re-visión: Enfoques en docencia e investigación. Universidad de A Coruña, La Coruña, 509-516.

(4) Hastings, M. (1955). St Stephen's Chapel and its place in the development of perpendicular style in England. Cambridge University Press, Cambridge.

(5) Harvey, J. (1968). "The tracing floor in York Minster". Annual Report of the Friends of York Minster, Vol. no. 40, 1-8.

(6) Holton, A. (2006). "The Working Space of the Medieval Master Mason: the Tracing Houses of York Minster and Wells Cathedral". In Proceedings of the Second International Congress on Construction History, 1579-1597.

(7) Colchester, L.S., Harvey, J. (1974). "Wells Cathedral". Archaeological Journal, Vol. 131, 200-214.

(8) Pinto Puerto, F., Jiménez Martín, A. (1993). "Monteas en la Catedral de Sevilla". Revista de Expresión Gráfica Arquitectónica (EGA), Vol. no. 1, 79-84.

(9) Taín Guzmán, M. (2003). "Las monteas de la Catedral de Santiago de Compostela: de la arquitectura a la escultura". In Correspondencia e Integración de las Artes. XIV Congreso Nacional de Historia del Arte, 509-522.

(10) Taín Guzmán, M. (2009). "La utilización de monteas en la construcción en piedra: El caso gallego". In El arte de la piedra. CEU Ediciones, Madrid, 171-202.

(11) Gómez-Moreno, M. (1963). Diego Siloé. Homenaje en el IV centenario de su muerte. Universidad de Granada, Granada.

(12) Bustamante García, A. (1994). La octava maravilla del mundo. Estudio histórico sobre el Escorial de Felipe II. Alpuerto, Madrid.

(13) Rosende Valdés, A.A. (1989). "Una muestra de arquitectura itinerante en Tuy: la capilla de San Telmo". In Los Caminos y el Arte. Actas del VI Congreso Español del Arte, vol. II, 271-283.

(14) Pereira Morales, A. (2006). Arquitecturas y arquitectos en la diócesis de Tui: siglos XVII y XVIII, A Coruña, 598-605.

(15) Iglesias Almeida, E. (2001). La Cofradía de San Pedro González Telmo: Patrono de la ciudad de Tui y su obispado, Tui, 66-67, 74, 77 y 79.

(16) Iglesias Almeida, E. (1989). Arte y Artistas en la antigua Diócesis de Tui, Tui.

(17) Archivo de la Catedral de Tui (A.C.T.) (1776). Protocolo Dionisio Manuel Herrero, fols. $25 \mathrm{r} .-27 \mathrm{v}$.

(18) A.C.T. (1776). Protocolo Dionisio Manuel Herrero, fols. 23r.-24r. 
(19) Archivo Histórico Diocesano de Tui, Cofradía de San Telmo, Coste de la Capilla, $n^{\circ} 4$, fols. 5 r.- $7 \mathrm{v}$.

(20) A.C.T., Libro de Actas Capitulares, t.22 (288), fol. 248r.v.

(21) A.C.T. (1790). Protocolo Dionisio Manuel Herrero Seoane, fols. 119r.-122r.; 123r.-125r.

(22) Tosca, T.V. (1707). Compendio mathemático, en que se contienen todas las materias más principales de las Ciencias, que tratan de la cantidad. Antonio Bordazar - Vicente Cabrera, Valencia.

(23) Martínez de Aranda, G. (c. 1600). Cerramientos y trazas de montea. Biblioteca del Servicio Histórico del Ejército.

(24) Portor y Castro, J. (1708). Cuaderno de arquitectura. Biblioteca Nacional, MS 9114.

(25) Vandelvira, A. (c. 1585). Libro de trazas de cortes de piedras. Biblioteca de la Escuela de Arquitectura de la Universidad Politécnica de Madrid.

(26) Calvo López, J., Molina Gaitán, J.C., Alonso Rodríguez, M.Á., López Mozo, A., Rabasa Díaz, E., Pozo Martínez, I., Sánchez Pravia, J.A. (2010). "El uso de monteas en los talleres catedralicios: el caso murciano". SEMATA, Ciencias Sociais e Humanidades, Vol. 22, 519-536.

(27) Alonso Rodríguez, M.Á., López Mozo, A., Farjas Abadía, M., Ayora Baena, F. (2002). "Levantamiento de la cúpula de la Basílica del Monasterio de San Lorenzo de El Escorial. Aplicación experimental de Estación Total de lectura directa". Topografía y Cartografía, Vol. no. 19, 19-33.

(28) Alonso Rodríguez, M.Á., Calvo López, J., Rabasa Díaz, E. (2009). "Sobre la configuración constructiva del crucero de la catedral de Segovia". In Actas del Sexto Congreso Nacional de Historia de la Construcción. Instituto Juan de Herrera, Madrid, 53-62.

(29) Alonso Rodríguez, M.Á., Calvo López, J. (2011). "Bóvedas baídas en el ámbito castellano. La iglesia de Navamorcuende (Toledo)". In Actas del Séptimo Congreso Nacional de Historia de la Construcción. Instituto Juan de Herrera, Madrid, 65-74.

(30) Anónimo (c. 1545). Manuscrito de cantería. Biblioteca Nacional de España, MS 12.686.

(31) Taín Guzmán, M., Natividad Vivó, P. (2011). “La montea para las bóvedas de horno de Santa Columba de Carnota". In Actas del Séptimo Congreso Nacional de Historia de la Construcción. Instituto Juan de Herrera, Madrid, 1387-1399. 